\title{
Characterization and Analysis of Okoume and Aiele Essential Oils from Gabon by GC-MS, Electronic Nose, and Their Antibacterial Activity Assessment
}

\author{
Youssra Aghoutane 1,2, Mohammed Moufid ${ }^{1,2}$, Soukaina Motia ${ }^{1,2}$, Guy Stephane Padzys 3 (D), \\ Linda Priscilia Omouendze ${ }^{3}$, Eduard Llobet ${ }^{4}{ }^{(D}$, Benachir Bouchikhi ${ }^{2}$ and Nezha El Bari ${ }^{1, *}$ \\ 1 Biosensors and Nanotechnology Group, Department of Biology, Faculty of Sciences, \\ Moulay Ismail University, B.P., Zitoune, Meknes 11201, Morocco; youssi.aghoutane@gmail.com (Y.A.); \\ mohammed.moufid.2@gmail.com (M.M.); sokainasafae@yahoo.fr (S.M.) \\ 2 Sensor Electronic \& Instrumentation Group, Department of Physics, Faculty of Sciences, \\ Moulay Ismail University, B.P., Zitoune, Meknes 11201, Morocco; benachir.bouchikhi@gmail.com \\ 3 Department of Biology, Faculty of Sciences, University of Sciences and Technolgy of Masuku, \\ Franceville 901, Gabon; padzys@gmail.com (G.S.P.); Priscilia.Omouendze@gmail.com (L.P.O.) \\ 4 Department of Electronic Engineering, Universitat Rovira i Virgili, MINOS-EMaS, \\ Microsystems and Nanotechnologies for Chemical Analysis, Avinguda Països Catalans, 26, \\ 43007 Tarragona, Spain; eduard.llobet@urv.cat \\ * Correspondence: n_elbari@hotmail.com; Tel.: +212-535-53-88-70; Fax: +212-535-53-68-08
}

Received: 23 October 2020; Accepted: 23 November 2020; Published: 26 November 2020

\begin{abstract}
Essential oil resins of Aucoumea klaineana (Okoume) and Canarium schweinfurthii (Aiele) species, of the Burseraceae family, were studied to investigate their bioactive constituents and their antibacterial activities. Aiele resin had a higher yield (6.86\%) of essential oil than Okoume (3.62\%). Twenty-one compounds for Okoume and eighteen for Aiele essential oil were identified using a gas chromatography-mass spectrometry (Gp-C-MS) technique. The main compounds identified in Okoume essential oil were benzenemethanol, $\alpha, \alpha, 4$-trimethyl (28.85\%), (+)-3-carene (3,7,7-trimethyl bicyclo[4.1.0]hept-3-ene) (17.93\%), D-Limonene ((4R)-1-methyl-4-prop-1-en-2-ylcyclohexene) (19.36\%). With regard to the Aiele essential oil, we identified (1R,4S)-1-methyl-4-propan-2-ylcyclohex-2-en-1-ol (26.64\%), and 1-methyl-4-propan-2-ylcyclohex-2-en-1-ol (26.83\%). Two strains of bacteria, Escherichia coli and Staphylococcus aureus, were used in antibacterial tests. S. aureus was found to be more sensitive to Okoume and Aiele essential oils, with a high inhibition zone ranging from 20 to $16 \mathrm{~mm}$. In comparison, the inhibition zone ranged from 6 to $12 \mathrm{~mm}$ for E. coli. An electronic nose (e-nose) combined with pattern analysis methods such as principal component analysis (PCA), discriminant function analysis (DFA), and hierarchical cluster analysis (HCA) were used to discriminate the essential oil samples. In summary, the e-nose and GC-MS allowed the identification of bioactive compounds in the essential oil samples, which have a strong antimicrobial activity, with satisfactory results.
\end{abstract}

Keywords: okoume; aiele; essential oils; electronic nose; gas chromatography-mass spectrometry; antimicrobial activity

\section{Introduction}

The Burseraceae are a medium-sized family comprising about 700 species in 17 to 19 genera. The family includes both trees and shrubs [1]. It is endemic to the tropics of Africa, Asia, America, and subtropics. It is also represented by a few taxa in some warm temperate regions. In this family, resin plants produce essential oils, which are mainly extracted from the leaves, bark, and oleaginous resins. These essential oils, also called volatile or ethereal oils [2], are aromatic oily liquids rich in 
many bioactive compounds, which have an important biological role as antibacterial [3], antifungal [4] agents, and are responsible for many medicinal properties [5]. Aucoumea klaineana Pierre, or okoume as it is commonly known in Gabon, and the species Canarium schweinfurthii or aiele, are the two most important wood species in Gabon [6].

The natural range of okoume is limited to western and central Gabon and the regions of Equatorial Guinea, the Republic of Congo, and Cameroon [7]. The Canarium schweinfurthii or aiele tree grows in the equatorial forest region of Cameroon, Central African Republic, Gabon, and Congo [8]. All these species produce a gum that solidifies into resin [9]. The resin is distilled to produce essential oil commonly used in traditional medicine and perfumery because of its lavender smell. Okoume resin is used to purify water, to ripen abscesses, and is applied as a substitute for incense. The bark can be employed as an antiseptic, astringent, or antidiarrheal agent [10,11]. In addition, aiele resin is used in traditional medicine for the treatment of various diseases such as cutaneous lesions and microbial infestations. It is also used for its emollient, stimulating, and diuretic properties [12].

Several methods have been proposed to identify volatile compounds contained in essential oils such as high-precision liquid chromatography (HPLC) [13], gas chromatography-mass spectrometry (GC-MS) [14], GC-MS combined with chemometric resolution methods [15], Two-Dimensional Gas chromatography (GC × GC) [16], and ATR-Fourier transform mid-infrared spectroscopy (FT-IR) [17]. However, most of these techniques are usually time-consuming and costly. Electronic noses have been explored as a more affordable approach to discriminate different essential oils [18].

The electronic nose (e-nose) is a device that integrates a group of gas sensors with partial specificity and an adequate pattern recognition system, able to recognize both simple and complex odors [19]. In e-nose devices, samples are analyzed and classified (in terms of quality) on the basis of their fingerprints or patterns obtained from their volatile compounds [20]. Electronic noses are fast, economical, convenient, and reliable devices for non-destructive testing [21]. Electronic noses are used for many applications such as product classification within the food industry sector [22-24], determination of the quality and storage life [25,26], recognizing the maturity of fruit [27-29], and assessment of adulterated products [30-33]. Many studies on the use of e-nose systems for assessing the quality and distinction of natural MAPs (medicinal and aromatic plants) have been described in the literature [34]. For instance, the quality control of Alpinia officinarum using an e-nose and GC-MS coupled with chemometrics [35], the discrimination and characterization of licorice (Glycyrrhiza glabra L.) roots utilizing electronic nose and HS-SPME/GC/MS analysis [36], as well as the quality control method for musk by an e-nose coupled with chemometrics [37]. Such an approach has also been envisaged for some other plants, including Mentha spicata L. [38], Cymbidium ensifolium [39], ginseng [40-42], Eurycoma longifolia [43], apiaceae [44], Cannabis sativa L. [45], Glycyrrhiza glabra L. [46], Citrus reticulata [47], as well as the classification of rosemary essential oil (Rosmarinus officinalis L.) [48].

The essential oils of resin contain a high percentage of compounds with known antibacterial and antifungal properties. Nowadays, bacterial infections remain a major cause of morbidity and mortality in humans and animals. The phenomenon of antibiotic-resistant bacteria continues to increase in frequency and number worldwide, and new resistance problems have recently emerged, which further complicates and hinders the treatment of critical infectious diseases [49]. Besides, the use of natural products such as essential oils as antimicrobial compounds has many advantages. These comprise fewer adverse effects, better patient tolerance, relative inexpensiveness, and wide acceptance because of their traditional applications, renewable nature, and better biodegradability [50].

To the best of our knowledge, no attempt has yet been made to investigate the compounds of okoume and aiele essential oils using (e-nose) combined with GC-MS. For these reasons, on the one hand, we investigated the capability of an e-nose coupled to various chemometric methods, namely principal component analysis (PCA), discriminant function analysis (DFA), and hierarchical cluster analysis (HCA), to first classify and discriminate between the two Gabonese essential oils of Canarium schweinfurthii (aiele), and Aucoumea klaineana (okoume). In addition, we determined the chemical composition and evaluated the efficacy and pure major compounds by GC-MS analysis. 
On the other hand, we used the aromatogram method to reveal their antibacterial activity in vitro against two bacteria strains Escherichia coli (Gram-) and Staphylococcus aureus (Gram+).

\section{Materials and Methods}

\subsection{Sample Preparation}

In this paper, two types of Gabonese essential oils called okoume and aiele of the medicinal plant family Burseraceae, were used. Aucoumea klaineana (okoume) and Canarium schweinfurthii (aiele) resins were collected in March 2017 in Djoutou South East Gabon. The resins were hydro-distilled for $3 \mathrm{~h}$ in a Clevenger-type apparatus. The essential oils were dried after decantation using anhydrous sodium sulfate, then filtered and stored under dark conditions at $4{ }^{\circ} \mathrm{C}$ before analysis. The percentage yield of essential oils has been calculated on the basis of the ratio (mass of dry oil extracted to mass of resin).

For performing the measurements, $0.5 \mathrm{~mL}$ of each essential oil were heated to $32 \pm 1{ }^{\circ} \mathrm{C}$, inside a thermostatically controlled sampling chamber for a headspace generation time of $10 \mathrm{~min}$ in order to analyze them using the e-nose system. These samples were subject to heating in a thermostatic bath at $95^{\circ} \mathrm{C}$ for $20 \mathrm{~min}$ for performing the GC-MS analysis.

\subsection{GC-MS Measurements}

The chemical analysis of the volatile atmospheres resulting from the essential oils was carried out using GC-MS. The analyses employed two instruments, a GC series 6890 with liquid automatic sampler series HP7683 coupled to a mass spectrometer 5972 (Agilent Technologies Inc., Santa Clara, CA, USA). The column used in chromatography was an HP5 analytical column (Agilent Technologies Inc.), with a length of $30 \mathrm{~m}$, an internal diameter of $0.25 \mathrm{~mm}$ and a $0.25 \mu \mathrm{m}$ thick stationary phase. In this case, the injections of the samples were done manually. The samples were weighed in vials of $10 \mathrm{~mL}$. Subsequently, a manual injection syringe was introduced into the headspace and the volatile sample was injected into the GC. The analysis method was as follows: injector: splitless; inlet pressure: $11.03 \mathrm{psi}$; inlet temp. $220^{\circ} \mathrm{C}$; column flow $1.3 \mathrm{~mL} / \mathrm{min}$; mode: constant flow; volume: $500 \mu \mathrm{L}$; temperature: initial T: $60{ }^{\circ} \mathrm{C}, 2 \mathrm{~min}$; ramp $3{ }^{\circ} \mathrm{C} / \mathrm{min}$ up to $90{ }^{\circ} \mathrm{C}, 9 \mathrm{~min}$; ramp $20{ }^{\circ} \mathrm{C} / \mathrm{min}$ up to $220^{\circ} \mathrm{C}, 2 \mathrm{~min}$; Analysis time: $20.5 \mathrm{~min}$; acquisition in full scan mode and range from 15 to $300 \mathrm{~m} / \mathrm{z}$. The mass spectra obtained from our GC-MS system were compared to those of the NIST11 MS database. Volatile compounds were tentatively identified via comparison of the spectrum recorded and those in the database when a high degree of similarity was found (equal to or higher than $80 \%$ ).

\subsection{Antibacterial Assay}

\subsubsection{Preparation of Bacterial Inoculum}

The antibacterial activity was performed on two strains of Gram-negative (E. coli (ATCC 25922)) and Gram-positive (S. aureus) bacteria, obtained from the microbiology laboratory of the Faculty of Science, Moulay Ismail University of Meknes (Morocco). The bacteria to be tested were sown on Petri dishes containing selective media adapted to the bacterial strains used and incubated at $37^{\circ} \mathrm{C}$ for $24 \mathrm{~h}$ to obtain well-isolated colonies. After this incubation time, 1 to 3 well isolated and perfectly identical bacterial colonies were collected using a platinum loop, then emulsified in a tube containing $2 \mathrm{~mL}$ of $0.9 \%$ sterile physiological water and vortexed. The inoculum was adjusted to $0.5 \mathrm{McFarland}$, corresponding to an optical density of (0.08 to 0.10$)$ at $625 \mathrm{~nm}$ [51].

The inoculum thus obtained was diluted in sterile physiological water depending on the type of germs:

- For Enterobacteriaceae, $100 \mu \mathrm{L}$ of inoculum were diluted in $10 \mathrm{~mL}$ of physiological water.

- For Staphylococcus, $1000 \mu \mathrm{L}$ of inoculum were diluted in $10 \mathrm{~mL}$ of physiological water.

This dilution allowed us to have a bacterial suspension at $107 \mathrm{CFU} / \mathrm{mL}$. 


\subsubsection{Antibacterial Testing}

The antibacterial activity of different essential oils was evaluated by the aromatogram method [52]. Briefly, the test was performed in sterile Petri dishes (100 $\mathrm{mm}$ diameter), previously poured by media (Müller Hinton ((Sigma Aldrich, Saint Louis, MO, USA) for bacteria), seeded with a microbial suspension $(107 \mathrm{cell} / \mathrm{mL})$. Then, sterile $6 \mathrm{~mm}$ diameter Wattmen paper discs, soaked with $10 \mu \mathrm{L}$ of each essential oil, were placed sterile on the surface of the culture media. After incubation for $24 \mathrm{~h}$ at $37^{\circ} \mathrm{C}$, the results are read by measuring the diameter, in $\mathrm{mm}$, of the inhibition zone. All experiments were repeated three times [51].

\subsection{Electronic Nose Setup Measurements}

An electronic nose system based on six semiconductor gas sensors obtained from Figaro Engineering, Inc. (Osaka, Japan). (Table 1) were used to analyze the two essential oils, okoume and aiele.

Table 1. Types of sensors used in the electronic nose and their principles.

\begin{tabular}{cc}
\hline Types of Sensors & Principles of Operation \\
\hline TGS 815 & High sensitivity and high selectivity to hydrogen \\
TGS 821 & Highly sensitive to organic solvent vapors and a wide variety of combustible gases such as carbon monoxide \\
TGS 822 & Organic solvents \\
TGS 824 & Ammonia \\
TGS 825 & Hydrogen sulfide \\
TGS 842 & Methane, hydrocarbons (domestic gas alarm) \\
\hline
\end{tabular}

The experimental system is mainly composed of three parts: a sampling unit, the sensor array, and a data acquisition system. An overall view of the system is shown in Figure 1. The data acquisition system registers the electrical signals generated from gas sensors due to the interaction of their sensitive surfaces with the volatile organic compounds (VOCs) released from essential oils. Each sample was placed in a $100 \mathrm{~mL}$ airtight glass vial with two small holes in their cover to allow the headspace to be analyzed with the e-nose equipment. Six replicates of each essential oil headspace (okoume, aiele) sample were measured without any pre-treatment.

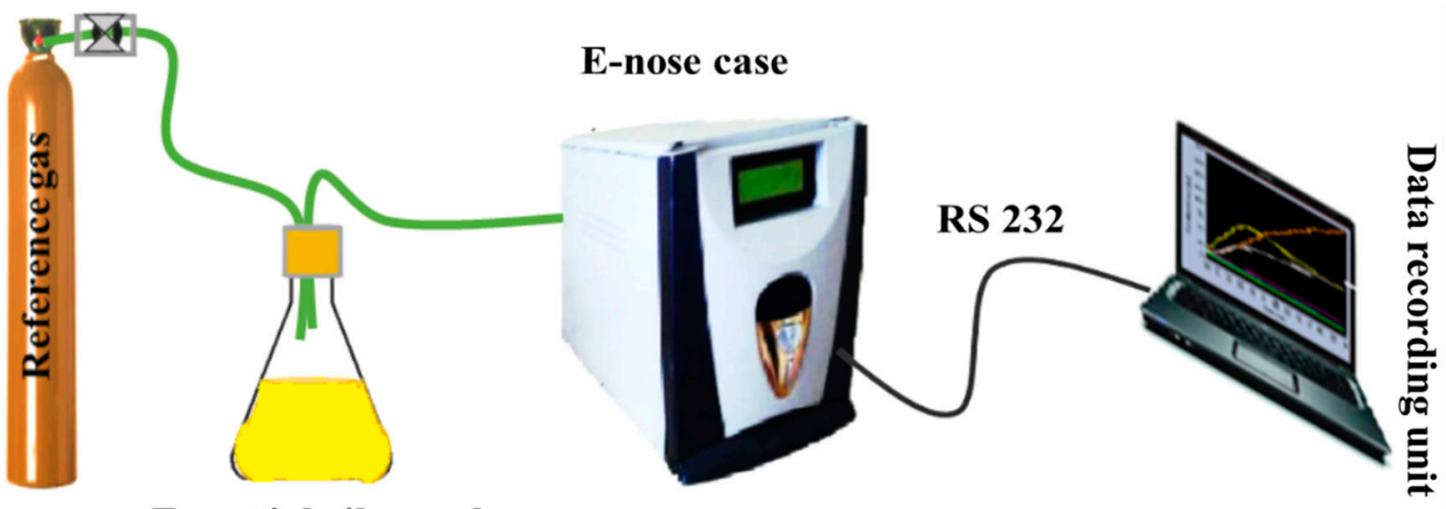

\section{Essential oil samples}

Figure 1. E-nose setup for essential oils (okoume and aiele) analysis.

\subsection{Statistical Analysis}

\subsubsection{Feature Extraction}

Feature extraction is an essential pre-processing step for pattern recognition $[31,53]$. The functions used for data analysis are automatically extracted from the gas sensor responses in order to extract the maximum amount of information available in the database. Consequently, for each measurement 
performed, four representative characteristics were extracted from the response of each sensor, which are as follows:

- G0, the initial sensor conductance determined as the average value of its conductance during the first minute of a measurement.

- Gs, which represents the steady state conductance determined as the average value of its conductance during the last minute of a measurement.

- $\mathrm{dG} / \mathrm{dt}$, which corresponds to the dynamic slope of the conductance determined between 2 and 9 min of measurement.

- $\mathrm{A}$, the area under the conductance curve during a defined time interval between 2 and 9 min of measurement. This area has been estimated by the trapezium method.

\subsubsection{Data Processing}

To evaluate the performance of the e-nose for the discrimination between the two Gabonese essential oils, multivariate unsupervised and supervised data analysis methods such as PCA, DFA, and HCA were applied.

Radar plots are particularly appropriate to illustrate the overall responses of the sensor system. A Radar plot is used to display the results generated by several sources and is strongly recommended when associated with a statistical study, since it frequently anticipates the classification of data groups. Unit radius radar plots were used in this study to check for differences between the two samples of okoume and aiele essential oils. This makes it easy to accurately visualize the differences between typical plots.

PCA is a powerful, unsupervised linear pattern recognition technique that has proven effective in easily visualizing the maximum amount of information in a data set. It decomposes the primary data matrix by projecting multidimensional data into a new coordinate database formed by orthogonal directions with maximum data variation.

The DFA method is the most frequently used and best-studied supervised pattern recognition method [54]. It is based on the determination of discriminant functions, which maximize the variance ratio between classes by minimizing the intra-class variance ratio. This technique constitutes the factorial method. Its objective is to examine whether or not the variables are sufficient to be able to classify correctly the data a posteriori into their a priori groups.

Finally, HCA refers to the unsupervised classification of patterns (vectors of characteristics) into groups (clusters) such that individuals in the same group are more similar than those in different groups [31]. In HCA, individuals are often represented in a dendogram. The distance between two objects in a dendrogram is evaluated to determine the similarity of the objects according to each of their attributes.

\section{Results and Discussion}

\subsection{Essential Oil Yield of Two Species}

The yields of essential oils for the two species selected in this work were $3.62 \%$ for Aucoumea klaineana resin and $6.86 \%$ for Canarium schweinfurthii resin. The essential oil yield of Canarium schweinfurthii resin was significantly higher than that of the Aucoumea klaineana.

\subsection{GC-MS Results}

The qualitative analysis of VOCs from the headspace of essential oils (okoume, aiele) was performed using GC-MS to identify the main compounds responsible for their benefits on well-being and health.

Figures 2 and 3 show that there are VOCs that were specific to an essential oil, and other VOCs that appear in the headspace of both essential oils. The amount of VOCs released by okoume essential 
oil samples was much higher than that of the aiele essential oil samples. Mass spectra were compared to the NIST11 mass spectra database and a compound was considered as identified provided that the match between our experiment and the database was $75 \%$ or higher. Using this technique, twenty-one compounds were identified from okoume essential oil, compared to eighteen compounds from aiele (Figure 2).

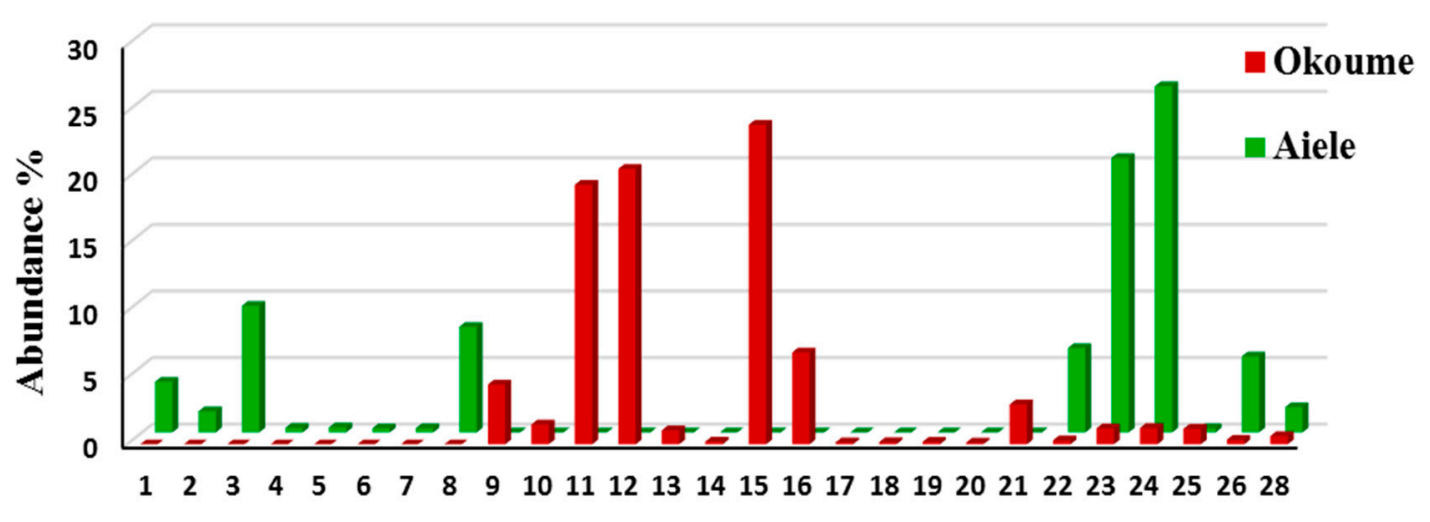

\section{VOCs number}

Figure 2. Histogram of the identified volatile compound of aiele and okoume essential oils by GC-MS analysis. The VOC numbers correspond to those used in Table 2.

Table 2 lists the main compounds that are tentatively identified in each sample, indicating their CAS number and chromatographic retention time (depending on the analytical method used). The degree of similarity of their spectra is also indicated.

Figure 3 shows that the chromatogram of okoume essential oil showed a significantly higher number of peaks than that of aiele essential oils. The first compound appeared at $1.63 \mathrm{~min}$. Then a succession of peaks of notable height appeared placed between different very small peaks. In all, there were four important peaks, between $t=10 \mathrm{~min}$ and $20 \mathrm{~min}$. In addition to this, there are five dominant peaks that appeared at about $15 \mathrm{~min}$ and $28.5 \mathrm{~min}$. Finally, other peaks with very small amplitudes were obtained. According to these results, the main components were $\alpha$-Terpineol (2-(4-methylcyclohex-3-en-1-yl)propan-2-ol) (29.04\% and 28.49\% for okoume and aiele essential oils, respectively), which was recorded in other studies on the composition of the Burseraceae family [55]. Benzenemethanol, $\alpha, \alpha$, 4-trimethyl (28.85\%), (+)-3-Carene (3,7,7-trimethyl bicyclo[4.1.0]hept-3-ene) (17.93\%), D-Limonene ((4R)-1-methyl-4-prop-1-en-2-ylcyclohexene) (19.36\%) for okoume essential oil. This result has been confirmed by previously published research conducted on the volatile oil of Aucoumea klaineana oleoresin harvested in Gabon [56]. (1S,4R)-4-Isopropyl-1-methyl-2-cyclohexen-1-ol) (25.90\%) and 2-cyclohexen-1-ol, 1-methyl-4-(1-methylethyl)-, cis(1-methyl-4-propan-2-ylcyclohex-2-en-1-ol) $(26.83 \%)$ were identified for aiele essential oil. These results are also in good agreement with previous works on the composition of essential oils in Canarium schweinfurthii (aiele) resin from Gabon [57]. Other predominant constituents were benzenemethanol, $\alpha, \alpha, 4$-trimethyl-(28.85\%), 1, 3, 8-p-Menthatriene(1-methyl-4-prop-1-en-2-yl-cyclohexa-1,3-diene) (24.91\%), bicyclo[2.2.1]heptan-2-one, 1,7,7-trimethyl-, (1S)-Camphor (26.92\%) for okoume and 1-methyl-4-propan-2-yl-cyclohexa-1,4-diene (22.31\%), 2-methyl-5-propan-2-yl bicyclo[3.1.0]hexan-2-ol (24.7\%), (4-methyl-1-propan-2-yl cyclohex-3-en-1-yl) acetate $(26.64 \%)$ for aiele. As can be derived from Table 2, the predominant shared compounds in aiele and okoume essential oils are o-cymene(1-methyl-2-propan-2-ylbenzene), (+)-4-Carene ((1R,4S,6S)-4,7,7-trimethylbicyclo[4.1.0]hept-2-ene). 
Table 2. Chemical composition of the essential oils of okoume and aiele, as identified by GC analysis.

\begin{tabular}{|c|c|c|c|}
\hline \multirow[b]{2}{*}{ VOC \# } & \multirow[b]{2}{*}{ Chemical Species Name (IUPAC Name) } & \multicolumn{2}{|c|}{ Essential Oil Samples Composition (\%) } \\
\hline & & $\begin{array}{c}\text { Aiele } \\
\text { (Canarium schweinfurthii) }\end{array}$ & $\begin{array}{c}\text { Okoume } \\
\text { (Aucoumea klaineana) }\end{array}$ \\
\hline 1 & ((5S)-2,6,6-trimethyl bicyclo[3.1.1]hept-2-ene & 12.41 & 0 \\
\hline 2 & 2-methyl-5-propan-2-yl cyclohexa-1,3-diene & 17.33 & 0 \\
\hline 3 & 1-methyl-4-propan-2-yl cyclohexa-1,4-diene & 22.31 & 0 \\
\hline 4 & 2-methyl-5-propan-2-yl bicyclo[3.1.0]hexan-2-ol & 24.70 & 0 \\
\hline 5 & (1S,4R)-4-Isopropyl-1-methyl-2-cyclohexen-1-ol & 25.90 & 0 \\
\hline 6 & (4-methyl-1-propan-2-yl cyclohex-3-en-1-yl) acetate & 26.64 & 0 \\
\hline 7 & 1-methyl-4-propan-2-ylcyclohex-2-en-1-ol & 26.83 & 0 \\
\hline 8 & 2-[(1S)-4-methyl cyclohex-3-en-1-yl]propan-2-ol & 29.03 & 0 \\
\hline 9 & Propan-2-one & 0 & 1.63 \\
\hline 10 & Toluene & 0 & 4.57 \\
\hline 11 & 2,6,6-trimethyl bicyclo[3.1.1]hept-2-ene & 0 & 12.45 \\
\hline 12 & 7,7-dimethy 1-2-methylidene bicyclo[2.2.1]heptane & 0 & 13.19 \\
\hline 13 & 2,2-dimethy l-3-methylidene bicyclo[2.2.1]heptane & 0 & 13.28 \\
\hline 14 & 6,6-dimethy 1-2-methylidenebicyclo[3.1.1]heptane & 0 & 15.12 \\
\hline 15 & 3,7,7-trimethyl bicyclo[4.1.0]hept-3-ene & 0 & 17.93 \\
\hline 16 & 1-methyl-4-(propan-2-yl)benzene & 0 & 19.26 \\
\hline 17 & (4R)-1-methyl-4-prop-1-en-2-ylcyclohexene & 0 & 19.36 \\
\hline 18 & 1-methyl-4-prop-1-en-2-yl cyclohexa-1,3-diene & 0 & 24.91 \\
\hline 19 & Bicyclo[2.2. 1]heptan-2-one, 1,7,7-trimethyl-, (1S)-Camphor. & 0 & 26.92 \\
\hline 20 & 4-methyl-1-(propan-2-yl)cyclohex-3-en-1-ol & 0 & 28.46 \\
\hline 21 & Benzenemethanol, $\alpha, \alpha, 4$-trimethyl- & 0 & 28.85 \\
\hline 22 & 2-(4-methylcyclohex-3-en-1-yl)propan-2-ol & 28.49 & 29.04 \\
\hline 23 & (1S)-2-methyl-5-propan-2-ylbicyclo[3.1.0]hex-2-ene & 12.13 & 24.18 \\
\hline 24 & 2,6,6-trimethyl bicyclo[3.1.1]hept-2-ene & 12.45 & 12.09 \\
\hline 25 & 1-methyl-2-propan-2-ylbenzene & 14.80 & 18.83 \\
\hline 26 & 4-methyl-1-propan-2-ylbicyclo[3.1.0]hex-2-ene & 15.06 & 19.25 \\
\hline 27 & $(1 \mathrm{R}, 4 \mathrm{~S}, 6 \mathrm{~S})-4,7,7$-trimethylbicyclo[4.1.0]hept-2-ene & 24.07 & 16.88 \\
\hline 28 & 1-methyl-4-propan-2-ylidenecyclohexane & 24.18 & 22.77 \\
\hline
\end{tabular}

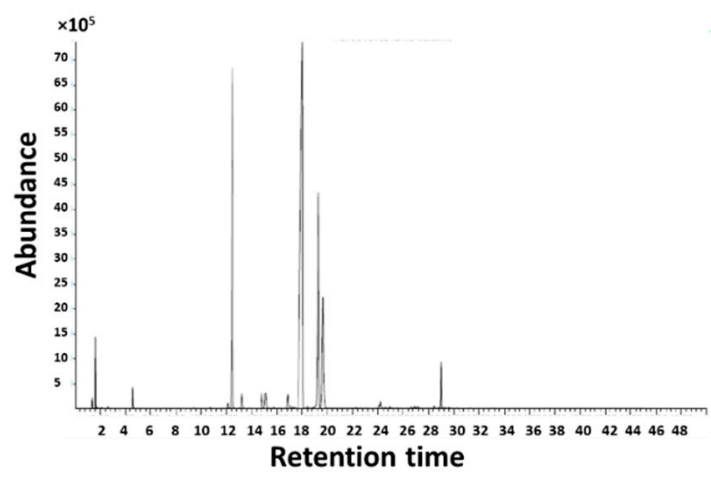

(a)

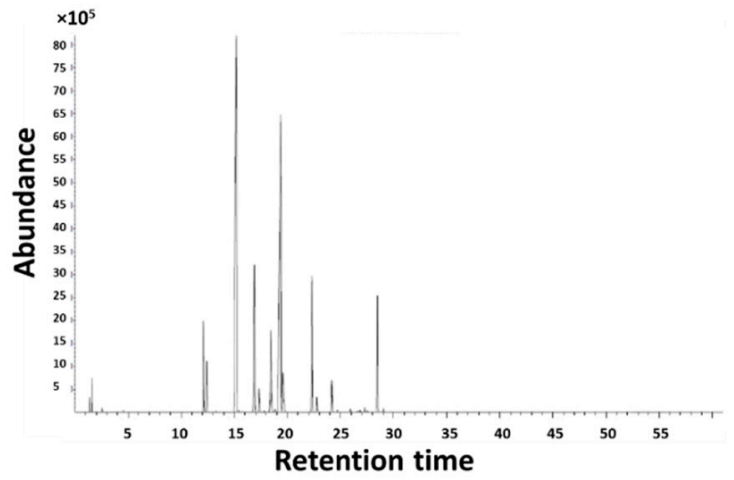

(b)

Figure 3. Total ion current (TIC) chromatogram of: (a) okoume and (b) aiele essential oils.

\subsection{Antibacterial Activity}

The results of the antibacterial test are summarized in Figure 4. They show that both the essential oil of okoume and aiele have a broad antibacterial activity because they inhibit the growth of Gram+ and Gram- bacteria, producing a zone of inhibition diameter (zdi) of 6 to $12 \mathrm{~mm}$ for E. coli and 16 to 
$20 \mathrm{~mm}$ for S. aureus, respectively. According to the results in Figure 4, S. aureus is sensitive to both essential oils. However, the inhibition zone is larger for the oil extracted from Aucoumea klaineana (okoume) than for the oil extracted from Canarium schweinfurthii (aiele). Based on these results, it can be stated that the essential oils showed a clear antimicrobial activity on all strains tested.

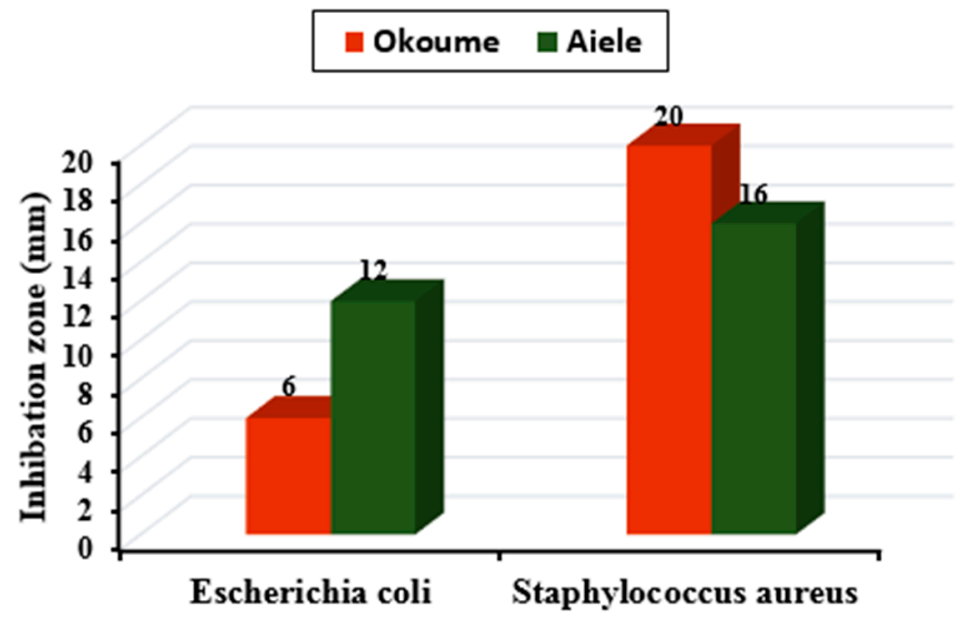

Figure 4. Antimicrobial effects of okoume and aiele essential oils on two pathogenic bacteria.

Okoume essential oil has a significant inhibitory effect against $S$. aureus $(20 \mathrm{~mm})$ and a moderate inhibitory effect for $E$. coli $(6 \mathrm{~mm})$. In the literature, essential oils with higher concentrations of components including: $\delta$-3-carene, linalool, $\alpha$-pinene, $\beta$-pinene, limonene, 1,8 -cineole [58], and terpineol [59] have been reported to show enhanced antibacterial activity. These findings are consistent with the results reported here for the essential oil extracted from Aucoumea klaineana (okoume).

An inhibitory effect for both strains was also observed for aiele essential oil. The literature shows that the presence of oxygenated monoterpenes, including 1, 8-cineole, linalool, -terpineol, nerolidol, and spathulenol, in high proportions results in antibacterial properties [60]. The essential oil of aiele is composed of relatively low proportions of some of these compounds and has been reported to show inhibitory activity. These reports are consistent with the results presented here. In particular, essential oils consist of complex mixtures of many constituents. The possible synergistic effects of the constituents present in the essential oil must also be taken into account. As mentioned above, okoume and aiele essential oils have a strong antimicrobial activity against these two bacteria: S. aureus (Gram+) and E. coli (Gram-). According to GC-MS results, okoume essential oil contains a high percentage of d-Limonene ((4R)-1-methyl-4-prop-1-en-2-yl-cyclohexene) (19.36\%), which is absent in aiele essential oil. This compound is considered to be the most toxic against $S$. aureus in comparison to other terpenes present [61]. A similar finding was reported for d-limonene-containing nano-emulsion, where $12.5 \mu \mathrm{g} \mathrm{mL}{ }^{-1}$ was required to inhibit E. coli, whereas Gram+S. aureus bacteria required only $3.125 \mu \mathrm{g} \mathrm{mL} \mathrm{m}^{-1}$ [62]. Our results confirm a higher antibacterial effect of okoume on S. aureus compared to Gram- bacteria (E. coli). This can also explain the strong sensitivity of S. aureus (Gram+) to Okoume and not to Aiele essential oil. Generally, the main antimicrobial active components, act against the cytoplasmic membrane of bacteria cell. The main mechanisms of action of okoume essential oil compounds (d-limonene ((4R)-1-methyl-4-prop-1-en-2-yl-cyclohexene), p-cymene (1-methyl-4-propan-2-ylbenzene) and 3-carene (3,7,7-trimethyl bicyclo[4.1.0]hept-3-ene)) are as follows. D-limonene ((4R)-1-methyl-4-prop-1-en-2-ylcyclohexene) acts against the cytoplasmic membranes of microorganisms, resulting in loss of membrane integrity, thus modifying its permeability and leading to the leakage of certain cellular components such as ions and proteins, dissipation of proton motive force and inhibition of respiratory enzymes [63]. Cymene can also cause an expansion of the cytoplasmic membrane, inducing a reduction of the membrane potential. Another study [64] suggested that the antimicrobial effects of p-cymene (1-methyl-4-propan-2-ylbenzene) may be due to 
a disruption of lipids in the bacterial membrane. p-cymene (1-methyl-4-propan-2-ylbenzene) may also have an impact on protein synthesis and cell motility, which was recently studied in E. coli O157:H7 [65]. Morphological changes induced by p-cymene (1-methyl-4-propan-2-ylbenzene) treatment have also been studied, showing damage in the morphological structure of the cell [66]. Similarly, 3-carene (3,7,7-trimethyl bicyclo[4.1.0]hept-3-ene) can damage the cell wall and cell membrane of Gram+ and Gram- bacteria, leading to leakage of protoplasmic contents [67] and reduction of proteins [68]. This, in turn, kills the bacteria and causes rapid degradation of ATP. Previous studies indicate that the sharp decrease in bacterial ATP concentration with the addition of 3-carene (3,7,7-trimethyl bicyclo[4.1.0]hept-3-ene) could be due to the inhibition of ATP synthesis, increased ATP hydrolysis, and interruption of biofilm structure, confirming damage to bacterial energy metabolism and biosynthetic pathways [69].

The antimicrobial activity of both essential oils (Okoume and Aiele) against the (Gram-) bacteria could be associated to the presence of monoterpenes ( $\alpha$-terpinene (1-methyl-4-propan-2-ylcyclohexa-1,3-diene)), 4-carene ((1R,4S,6S)-4,7,7-trimethylbicyclo[4.1.0]hept-2-ene), p-cymene (1-methyl-4-propan-2-ylbenzene), (+)-3-Carene (3,7,7-trimethyl bicyclo[4.1.0]hept-3-ene). Previous studies indicated that these compounds have synergistic antibacterial activity. Another study [70] examined the essential oil of Glossogyne tenuifolia, and its various compounds (including $p$-cymene (1-methyl-4-propan-2-ylbenzene)) against some common food pathogens. $p$-cymene (1-methyl-4-propan-2-ylbenzene) was found to be the most common compound in this oil. A minimum bactericidal concentration of $12 \mathrm{mg} / \mathrm{mL}$ of $p$-cymene (1-methyl-4-propan-2-ylbenzene) completely inhibited E. coli O157:H7, and S. aureus showed a minimum microbicidal concentration of $6 \mathrm{mg} / \mathrm{mL}$, in addition $p$-cymene (1-methyl-4-propan-2-ylbenzene) can induce significant synergistic antibacterial activity with other compounds such as limonene and $\alpha$-terpinene. That increased the antibacterial effect against pathogenic bacteria [71]. In addition, the low sensitivity of Gram - bacteria compared to the Gram + bacteria found for both essential oils is probably due to the presence of an external lipopolysaccharide membrane that acts as a physical barrier to lipophilic compounds, including essential oils [72]. Further studies on the combination of these essential oils with conventional antibiotics are needed to offer a promising and significant potential for the development of new therapies in the treatment of infectious diseases caused by multi-resistant microorganisms.

\subsection{Electronic Nose Results}

\subsubsection{Sensor Responses}

The volatile compounds generated from the essential oil were pumped with a flow rate of $100 \mathrm{~mL} / \mathrm{min}$ through the measurement chamber containing the sensor array. Upon injecting the sample, data were acquired every $2 \mathrm{~s}$ over $10 \mathrm{~min}$. Figure 5 shows typical signals of the normalized conductance of the six TGS gas sensors exposed to the headspace of the two types of essential oils from the same family plants, okoume (Figure 5a) and aiele (Figure 5b). Among the six different gas sensors present in the array, the TGS 815 gas sensor showed the highest response to the two types of essential oils.

\subsubsection{Radar Plot Representation}

Radar-plots with unitary radius were used to observe whether pattern differences (i.e., fingerprints) developed between essential oil samples. As can be seen, the radar plots (Figure 6) show a clear variation between two essential oils (okoume, aiele). To construct these plots, the values of delta $G$ for the sensor responses were divided by the value corresponding to sensor TGS 825, which showed the maximum signal. This helped to visualize the differences among typical response patterns. Indeed, a clear pattern variation (fingerprint) exists between okoume and aiele, which confirms the ability of the e-nose to easily discriminate between the two types of essential oils using the radar plot representation. 


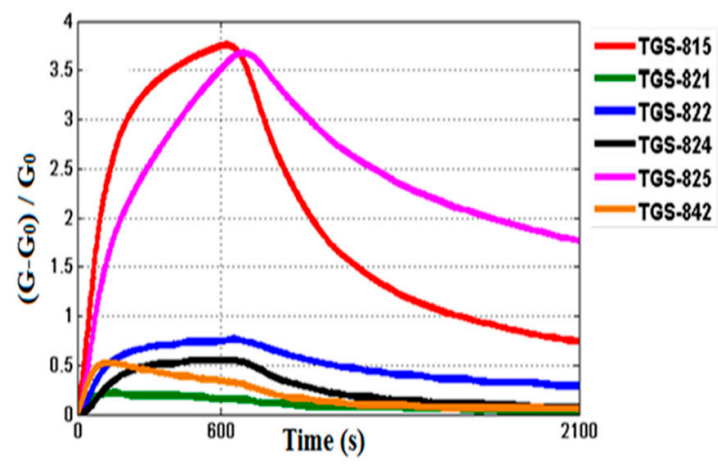

(a)

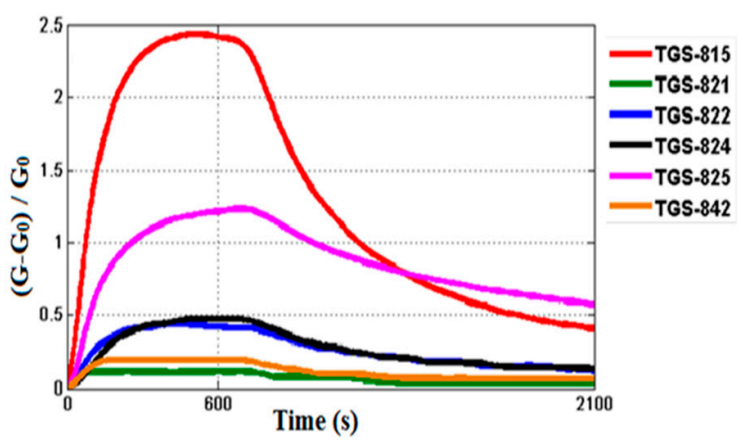

(b)

Figure 5. Sensor electrical conductance changes in the presence of (a) okoume, (b) aiele essential oils using an electronic nose system.

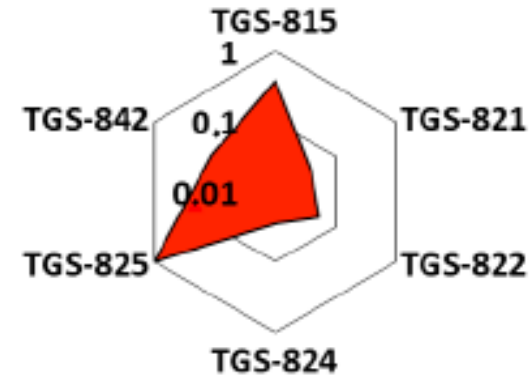

(a)

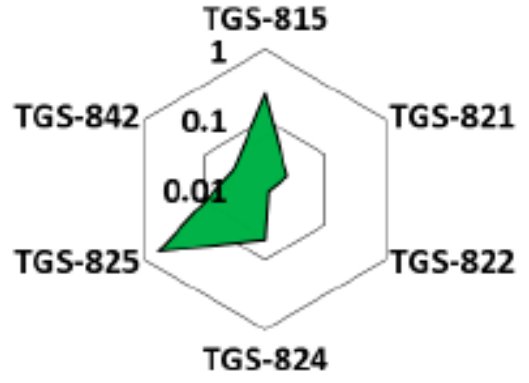

(b)

Figure 6. Radar plots of (a) okoume, (b) aiele essential oils using the conductance change (Delta-G) of sensors as response feature.

\subsubsection{Principal Component Analysis}

The PCA method was applied as an exploratory technique to study the clustering of data points in the multidimensional dataset. Before approaching the different classification tasks by PCA, it is necessary to reduce the size of the data matrix by selecting variables containing differential information, as the number of variables selected depends on the classification task [60]. In a first step, the data matrix was analyzed using the PCA technique to characterize and discriminate okoume and aiele essential oils. Figure 7 shows the projections of the experimental results on a three-dimensional (3D) graph using the first three new main components. Showing a cumulated variance of the first three principal components explain $49.56 \%, 28.66 \%$, and $11.88 \%$, respectively (i.e., $90.22 \%$ ) of the total data variance. From this figure, it can be noticed that the two types of essential oils can be perfectly discriminated by the e-nose in spite of the method uncertainty (i.e., variability within each class) caused mainly by variability in sensor response. On the one hand, the loadings matrix of (PC) was carried out using three features (normalized delta G, slope, and area) multiplied by the six sensors. The score plot is shown in Figure 7. Moreover, the discrimination obtained by the PCA is in good concordance with the specific VOCs that are identified by GC-MS in each essential oil. In particular, okoume essential oils contained some distinctive volatiles (i.e., acetone, toluene, pinenes, and terpenes) that do not appear in the essential oil of aiele. Sensor TGS 822 is quite sensitive to organic solvents such as toluene and acetone and, indeed the response of this sensor to volatiles from okume is significantly higher than for volatiles from aiele (see Figure 6). These differences may explain the discrimination between the two essential oils reached by the e-nose instrument using PCA. 


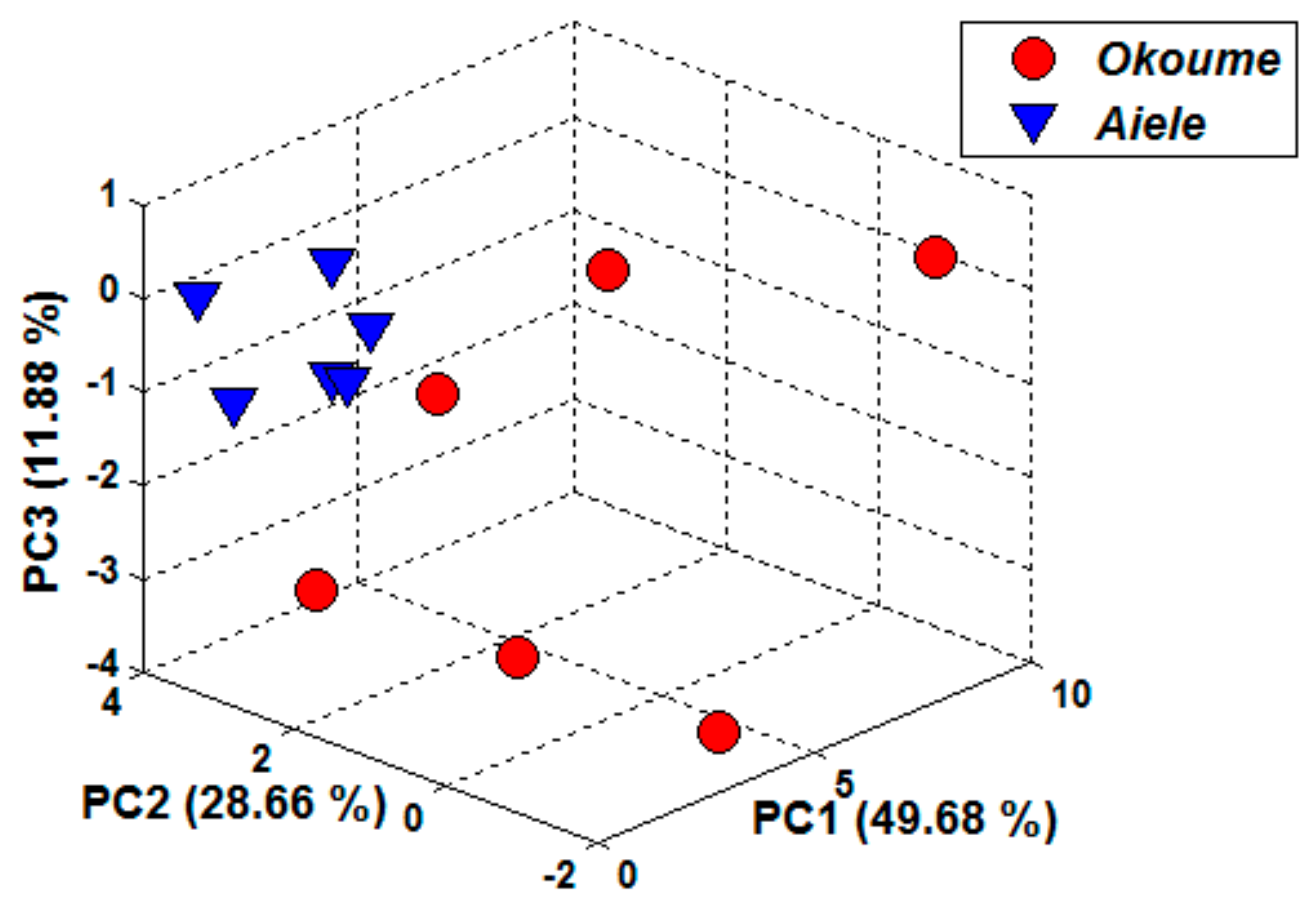

Figure 7. Three-dimensional PCA plot performed on essential oils, namely, okoume and aiele, using the conductance change (Delta-G) of sensors as a response feature.

Figure 8 shows a biplot for the PCA analysis for the first two principal components. In the biplot, scores for the two essential oils correspond to the black symbols, and the loadings are represented by the red and blue symbols. The plot suggests that the information given by the slope (+) and the normalized conductance change $\left(^{*}\right)$ is somewhat anti-correlated, as their associated loadings appear at an angle of about 180 degrees across the center. In contrast, the information given by the area under the response curve (o) is somewhat orthogonal to both the information given by the slope and conductance change, as their loadings appear at an angle of about 90 degrees across the center. The loadings varied significantly from sensor to sensor, so it can be concluded that the six sensors used are useful for achieving a good discrimination performance.

\subsubsection{Discriminant Function Analysis}

The performance of the e-nose system in the classification of essential oil samples into two groups was evaluated applying DFA method. These groups correspond to those also separated by PCA. Figure 9 shows the DFA performed on two types of essential oils, okoume and aiele. We can see from this figure that all samples are perfectly separated from each other. These results confirm that the e-nose system was able to discriminate different types of essential oils that come from the same family plants.

\subsubsection{Hierarchical Cluster Analysis}

The HCA provides an alternative for the visual representation of high-dimensional data. The results are illustrated in Figure 10 in the form of a dendrogram obtained from the essential oil samples by applying the Euclidean distance and Ward's link to define the groups. At link. dist =9, it can be seen that all the samples are grouped into two separate groups, corresponding to the essential oils analyzed. However, samples 2, 3, and 4 belonging to okoume oil are misclassified as aiele oil. The overlaps obtained may be due to the fact that the essential oils possess certain compounds in common according to the results obtained by GC-MS. This proves that the grouping classifications were highly correlated to the GC-MS results. In addition, this result does not contradict the PCA results in which okoume 
samples show a rather high dispersion in the score plot. Some okoume samples have scores that appear closer to the centroid for aiele, which possibly explains their misclassification by HCA.

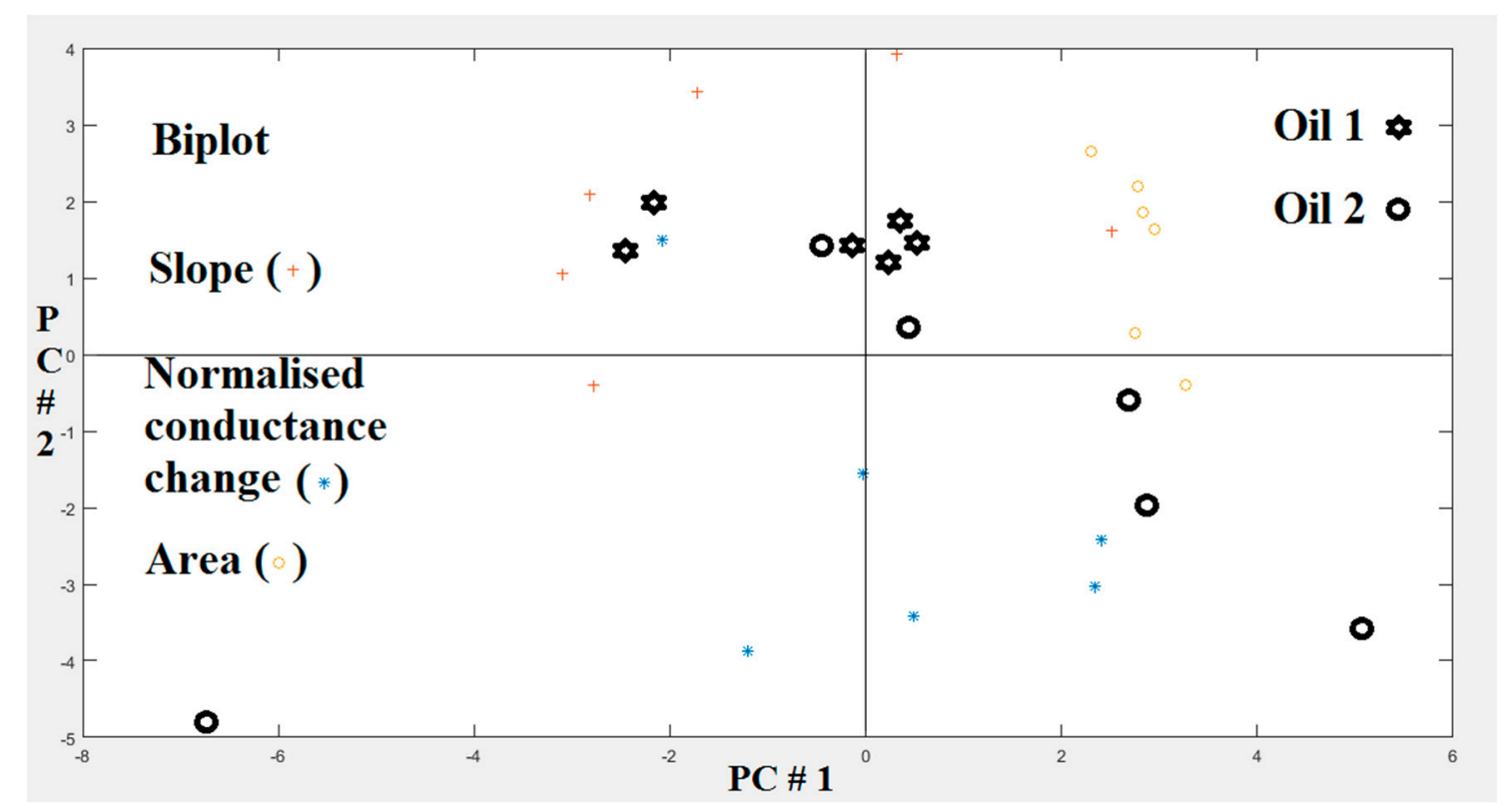

Figure 8. PCA biplot displaying samples of essential oils using conductance change (Delta-G), slope, and area.

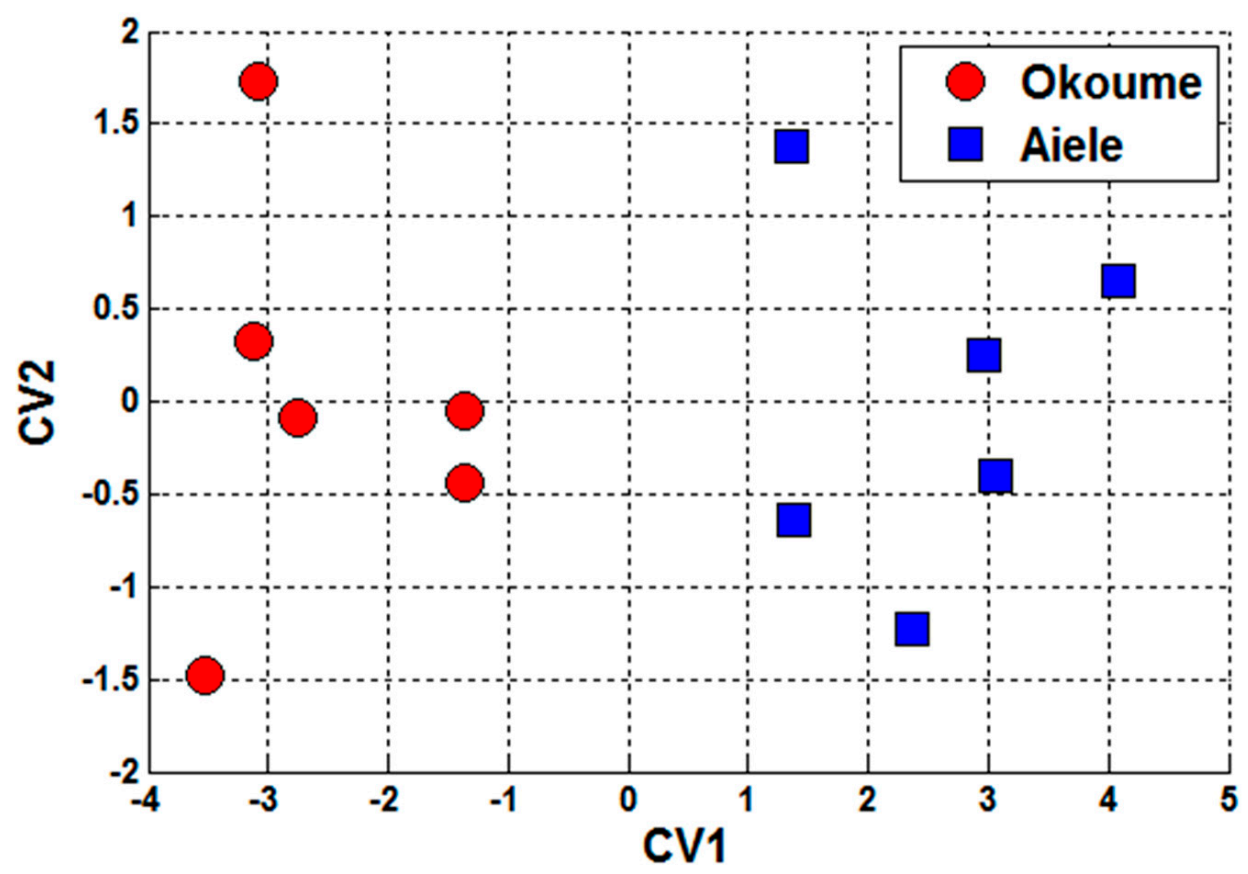

Figure 9. Discriminant function analysis (DFA) plot performed on essential oils, namely, okoume and aiele, using the conductance change (Delta-G) of sensors as a response feature. 


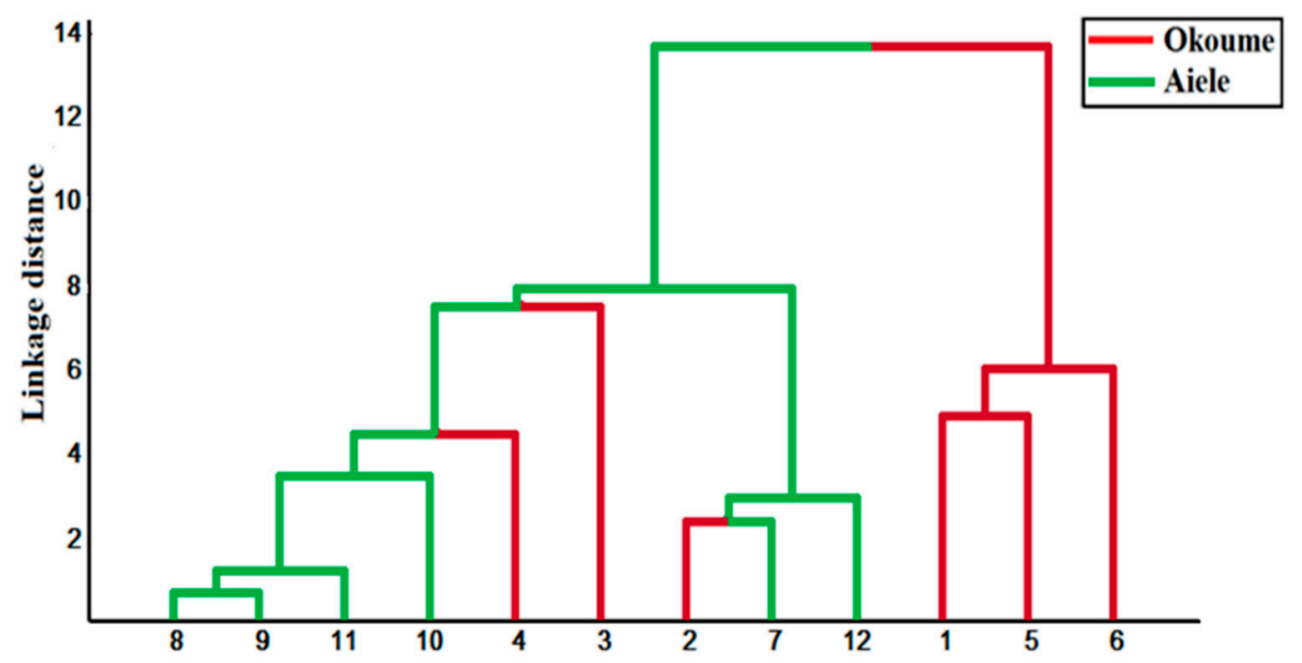

Figure 10. Hierarchical cluster analysis (HCA) dendrogram of the two essential oil samples measured using the conductance change (Delta-G) of sensors as a response feature.

\section{Conclusions}

The multi-strategy approach used in this study for the tasks of classification and detection of volatile bioactive compounds with antibacterial activity made it possible to highlight the differentiation of the samples of the essential oils studied. Moreover, a GC-MS technique was used to identify and qualitatively assess the content of bioactive compounds in the essential oil samples. As a result, twenty-one compounds for okoume and eighteen for aiele essential oil were identified. The main compounds were o-cymene(1-methyl-2-propan-2-ylbenzene), (+)-4-Carene ((1R,4S,6S)-4,7,7-trimethylbicyclo[4.1.0]hept-2-ene), 2-(4-methylcyclohex-3-en-1-yl)propan-2-ol for both essential oils. Benzenemethanol, $\alpha, \alpha, 4$-trimethyl-(28.85\%), (+)-3-Carene (3,7,7-trimethyl bicyclo[4.1.0]hept-3-ene) (17.93\%), D-Limonene ((4R)-1-methyl-4-prop-1-en-2-ylcyclohexene) $(19.36 \%)$ for the okoume essential oil. 1-methyl-4-propan-2-yl-cyclohexa-1,4-diene $(22.31 \%)$, 2-methyl-5-propan-2-yl bicyclo[3.1.0]hexan-2-ol (24.7\%), (4-methyl-1-propan-2-yl cyclohex-3-en-1-yl) acetate $(26.64 \%)$ for the aiele essential oil. On the one hand, the electronic nose, combined with several chemometric techniques, has demonstrated a great ability at discriminating between the two types of essential oils from the same plant family. Likewise, the results of the DFA lead to a satisfactory classification for all analyzed samples. In general, the essential oils have some common compounds according to the results obtained by GC-MS, which may explain the three misclassified samples when HCA was used. This proves that the grouping classifications of the e-nose were highly correlated with the GC-MS results. On the other hand, the combination of the e-nose system and GC-MS allowed the identification of bioactive compounds in the essential oil samples that have strong antimicrobial activity against the two bacteria tested, i.e., S. aureus and E. coli. This is because both essential oils contain monoterpenes, which have a strong antibacterial activity. Therefore, the use of such tools can ensure the determination of bioactive compounds in essential oils, which can be used against antibiotic-resistant bacteria.

Author Contributions: Y.A.: experimentation, formal analysis, writing; M.M.: software, data analysis; S.M.: experimentation, data analysis; G.S.P.: sample collection; L.P.O.: sample collection; E.L.: experimentation, writing reviewing; B.B.: writing reviewing, funding acquisition; N.E.B.: conceptualization, supervision, validation, project administration, resources, funding acquisition, writing and reviewing. All authors have read and agreed to the published version of the manuscript.

Funding: The authors would like to thank the financial support of Moulay Ismail University "Scientific Research Promotion 2018".

Acknowledgments: E.L. is supported by the Catalan Institution for Research and Advanced Studies via the 2018 Edition of the ICREA Academia Award. 
Conflicts of Interest: The authors declare no conflict of interest.

\section{References}

1. Daly, D.C.; Harley, M.M.; Martínez-Habibe, M.C.; Weeks, A. Burseraceae. In Flowering Plants. Eudicots; Springer: Berlin/Heidelberg, Germany, 2010; pp. 76-104.

2. Andoğan, B.C.; Baydar, H.; Kaya, S.; Demirci, M.; Özbaşar, D.; Mumcu, E. Antimicrobial activity and chemical composition of some essential oils. Arch. Pharm. Res. 2002, 25, 860-864. [CrossRef] [PubMed]

3. Camarda, L.; Dayton, T.; Di Stefano, V.; Pitonzo, R.; Schillaci, D. Chemical composition and antimicrobial activity of some oleogum resin essential oils from Boswellia spp. (Burseraceae). Ann. Chim. J. Anal. Environ. Cultural Herit. Chem. 2007, 97, 837-844.

4. Pontes, W.J.; De Oliveira, J.C.; Da Camara, C.A.; Lopes, A.C.; Gondim, M.G.C.; De Oliveira, J.V.; Schwartz, M.O. Composition and acaricidal activity of the resin's essential oil of Protium bahianum Daly against two spotted spider mite (Tetranychus urticae). J. Essent. Oil Res. 2007, 19, 379-383. [CrossRef]

5. Costa, A.F. Farmacognosia, Fundação Calouste Gulbenkian. Lisboa 2002, 2, 788-790.

6. Wasseige, C.; Devers, D.; deMarcen, P.; Eba'a Atyi, R.; Nasi, R.M.P.; Mayaux, P. Congo Basin Forests-State of Forests 2008; Publications Office of the European Union: Luxembourg, 2009.

7. Obiang, N.L.E.; Ngomanda, A.; Hymas, O.; Chézeauxl, É.; Picard, N. Diagnosing the demographic balance of two light-demanding tree species populations in central Africa from their diameter distribution. For. Ecol. Manag. 2014, 313, 55-62. [CrossRef]

8. Obame, L.C.; Koudou, J.; Kumulungui, B.S.; Bassolé, I.H.; Edou, P.; Ouattara, A.S.; Traoré, A.S. Antioxidant and antimicrobial activities of Canarium schweinfurthii Engl. essential oil from Centrafrican Republic. Afr. J. Biotechnol. 2007, 6. [CrossRef]

9. Nagawa, C.; Böhmdorfer, S.; Rosenau, T. Chemical composition and anti-termitic activity of essential oil from Canarium schweinfurthii Engl. Ind. Crops Prod. 2015, 71, 75-79. [CrossRef]

10. Raponda-Walker, A.; Sillans, R. Les plantes utiles du Gabon. Q. J. Crude Drug Res. 1961, 1, 27. [CrossRef]

11. White, L.; Abernethy, K. Guide de la Végétation de la Réserve de la Lopé; Ecofac: Libreville, Gabon, 1996.

12. Koudou, P.J. Etude Phytochimique, Activités Antimicrobiennes et Antioxydantes de Quelques Plantes Aromatiques et Médicinales Africaines. Ph.D. Dissertation, Université de Ouagadougou, Ouagadougou, Burkina Faso, 2009.

13. Al-Saman, M.A.; Abdella, A.; Mazrou, K.E.; Tayel, A.A.; Irmak, S. Antimicrobial and antioxidant activities of different extracts of the peel of kumquat (Citrus japonica Thunb). J. Food Meas. Charact. 2019, 13, 3221-3229. [CrossRef]

14. Daferera, D.J.; Ziogas, B.N.; Polissiou, M.G. GC-MS analysis of essential oils from some Greek aromatic plants and their fungitoxicity on Penicillium digitatum. J. Agric. Food Chem. 2000, 48, 2576-2581. [CrossRef] [PubMed]

15. Wang, Y.; Yi, L.; Liang, Y.; Li, H.; Yuan, D.; Gao, H.; Zeng, M. Comparative analysis of essential oil compounds in Pericarpium Citri Reticulatae Viride and Pericarpium Citri Reticulatae by GC-MS combined with chemometric resolution method. J. Pharm. Biomed. Anal. 2008, 46, 66-74. [CrossRef] [PubMed]

16. Dimandja, J.M.D.; Stanfill, S.B.; Grainger, J.; Patterson, D.G., Jr. Application of comprehensive two-dimensional gas chromatography $(\mathrm{GC} \times \mathrm{GC})$ to the qualitative analysis of essential oils. J. High Res. Chromatogr. 2000, 23, 208-214. [CrossRef]

17. Yan, T.; Chen, Y.; Shang, L.; Li, G. Assessment of essential oils from five Santalum species using ATR-fourier transform mid-infrared spectroscopy and GC-MS combined with chemometric analysis. J. Essent. Oil Res. 2020, 32, 150-157. [CrossRef]

18. Ide, J.; Nakamoto, T.; Moriizumi, T. Development of odor-sensing system using an auto-sampling stage and identification of natural essential oils. In Olfaction and Taste XI; Springer: Tokyo, Japan, 1994; pp. 727-730.

19. El Barbri, N.; Llobet, E.; El Bari, N.; Correig, X.; Bouchikhi, B. Electronic nose based on metal oxide semiconductor sensors as an alternative technique for the spoilage classification of red meat. Sensors 2008, 8, 142-156. [CrossRef] [PubMed]

20. Peris, M.; Escuder-gilabert, L. A 21st century technique for food control: Electronic noses. Anal. Chim. Acta 2009, 638, 1-15. [CrossRef] 
21. Loutfi, A.; Coradeschnii, S.; Ma, G.K.; Shankar, P.; Rayappan, J.B.B. Electronic noses for food quality: A review. J. Food Eng. 2015, 144, 103-111. [CrossRef]

22. Tahri, K.; Tiebe, C.; Bougrini, M.; Saidi, T.; El Alami El Hassani, N.; El Bari, N.; Hübertb, T.; Bouchikhi, B. Characterization and discrimination of saffron by multisensory systems, SPME-GC-MS and UV-Vis spectrophotometry. Anal. Methods UK 2015, 24, 10328-10338. [CrossRef]

23. Qiu, S.; Wang, J. Application of sensory evaluation, HS-SPME GC-MS, e-nose, and e-tongue for quality detection in citrus fruits. J. Food Sci. 2015, 80, 2296-2304. [CrossRef]

24. Trirongjitmoah, S.; Juengmunkong, Z.; Srikulnath, K.; Somboon, P. Classification of garlic cultivars using an electronic nose. Comput. Electron. Agric. 2015, 113, 148-153. [CrossRef]

25. Gomez, A.H.; Wang, J.; Hu, G.; Pereira, A.G. Discrimination of storage shelf-life for mandarin by electronic nose technique. LWT Food Sci. Technol. 2007, 40, 681-689. [CrossRef]

26. Benedetti, S.; Buratti, S.; Spinardi, A.; Mannino, S.; Mignani, I. Electronic nose as a non-destructive tool to characterise peach cultivars and to monitor their ripening stage during shelf-life. Postharvest Biol. Technol. 2008, 47, 181-188. [CrossRef]

27. Brezmes, J.; Fructuoso, M.L.L.; Llobet, E.; Vilanova, X.; Recasens, I.; Orts, J.; Saiz, G.; Correig, X. Evaluation of an electronic nose to assess fruit ripeness. IEEE Sens. J. 2005, 5, 97-108. [CrossRef]

28. Zakaria, A.; Shakaff, A.Y.M.; Masnan, M.J.; Saad, F.S.A.; Adom, A.H.; Ahmad, M.N.; Jaafar, M.N.; Abdullah, A.H.; Kamarudin, L.M. Improved maturity and ripeness classifications of magnifera indica cv. harumanis mangoes through sensor fusion of an electronic nose and acoustic sensor. Sensors 2012, 12, 6023-6048. [CrossRef] [PubMed]

29. Asikin, Y.; Maeda, G.; Tamaki, H.; Mizu, M.; Oku, H.; Wada, K. Cultivation line and fruit ripening discriminations of Shiikuwasha (Citrus depressa Hayata) peel oils using aroma compositional, electronic nose, and antioxidant analyses. Food Res. Int. 2015, 67, 102-110. [CrossRef]

30. Bougrini, M.; Tahri, K.; Haddi, Z.; Saidi, T.; El Bari, N.; Bouchikhi, B. Detection of adulteration in argan oil by using an electronic nose and a voltammetric electronic tongue. J. Sens. 2014, 2014. [CrossRef]

31. Tahri, K.; Tiebe, C.; El Bari, N.; Hübert, T.; Bouchikhi, B. Geographical provenience differentiation and adulteration detection of cumin by means of electronic sensing systems and SPME-GC-MS in combination with different chemometric approaches. Anal. Methods 2016, 8, 7638-7649. [CrossRef]

32. Kiani, S.; Minaei, S.; Ghasemi-Varnamkhasti, M. Instrumental approaches and innovative systems for saffron quality assessment. J. Food Eng. 2018, 216, 1-10. [CrossRef]

33. Marina, A.M.; Che Man, Y.B.; Amin, I. Use of the SAW sensor electronic nose for detecting the adulteration of virgin coconut oil with RBD palm kernel olein. J. Am. Chem. Soc. 2010, 87, 263-270. [CrossRef]

34. Kiani, S.; Minaei, S.; Ghasemi-Varnamkhasti, M. Application of electronic nose systems for assessing quality of medicinal and aromatic plant products: A review. J. Appl. Res. Med. Aromat. Plants 2016, 3, 1-9. [CrossRef]

35. Long, Q.; Li, Z.; Han, B.; Gholam Hosseini, H.; Zhou, H.; Wang, S.; Luo, D. Discrimination of Two Cultivars of Alpinia Officinarum Hance Using an Electronic Nose and Gas Chromatography-Mass Spectrometry Coupled with Chemometrics. Sensors 2019, 19, 572. [CrossRef]

36. Russo, M.; Serra, D.; Suraci, F.; Di Sanzo, R.; Fuda, S.; Postorino, S. The potential of e-nose aroma profiling for identifying the geographical origin of licorice (Glycyrrhiza glabra L.) roots. Food Chem. 2014, 165, 467-474. [CrossRef] [PubMed]

37. Ye, T.; Jin, C.; Zhou, J.; Li, X.; Wang, H.; Deng, P.; Yang, Y.; Wu, Y.; Xiao, X. Can odors of TCM be captured by electronic nose? The novel quality control method for musk by electronic nose coupled with chemometrics. J. Pharm. Biomed. Anal. 2011, 55, 1239-1244. [CrossRef] [PubMed]

38. Kia, S.; Minaei, S.; Ghasemi-Varnamkhasti, M. Real-time aroma monitoring of mint (Mentha spicata L.) leaves during the drying process using electronic nose system. Measurement 2018, 124, 447-452.

39. Zhang, B.; Huang, Y.; Zhang, Q.; Liu, X.; Li, F.; Chen, K. Fragrance discrimination of Chinese cymbidium species and cultivars using an electronic nose. Sci. Hortic. 2014, 172, 271-277. [CrossRef]

40. Lee, S.K.; Kim, J.H.; Sohn, H.J.; Yang, J.W. Changes in aroma characteristics during the preparation of red ginseng estimated by electronic nose, sensory evaluation and gas chromatography/mass spectrometry. Sens. Actuators B Chem. 2005, 106, 7-12. [CrossRef]

41. Li, S.; Li, X.R.; Wang, G.L.; Nie, L.X.; Yang, Y.J.; Wu, H.Z.; Wei, F.; Zhang, J.; Tian, J.G.; Lin, R.C. Rapid discrimination of Chinese red ginseng and Korean ginseng using an electronic nose coupled with chemometrics. J. Pharm. Biomed. Anal. 2012, 70, 605-608. [CrossRef] 
42. Cui, S.; Wang, J.; Yang, L.; Wu, J.; Wang, X. Qualitative and quantitative analysis on aroma characteristics of ginseng at different ages using e-nose and GC-MS combined with chemometrics. J. Pharm. Biomed. Anal. 2015, 102, 64-77. [CrossRef]

43. Li, C.; Xu, F.; Cao, C.; Shang, M.Y.; Zhang, C.Y.; Yu, J.; Liu, G.X.; Wang, X.; Cai, S.Q. Comparative analysis of two species of Asari Radix et Rhizoma by electronic nose, headspace GC-MS and chemometrics. J. Pharm. Biomed. Anal. 2013, 85, 231-238. [CrossRef]

44. Islam, A.S.; Ismail, Z.; Saad, B.; Othman, A.R.; Ahmad, M.N.; Shakaff, A.M. Correlation studies between electronic nose response and headspace volatiles of Eurycoma longifolia extracts. Sens. Actuators B Chem. 2006, 120, 245-251. [CrossRef]

45. Xiong, Y.; Xiao, X.; Yang, X.; Yan, D.; Zhang, C.; Zou, H.; Lin, H.; Peng, L.; Xiao, X.; Yan, Y. Quality control of Lonicera japonica stored for different months by electronic nose. J. Pharm. Biomed. Anal. 2014, 91, 68-72. [CrossRef]

46. Wasilewski, T.; Migoń, D.; Gębicki, J.; Kamysz, W. Critical review of electronic nose and tongue instruments prospects in pharmaceutical analysis. Anal. Chim. Acta 2019, 1077, 14-29. [CrossRef] [PubMed]

47. Hui, G.; Jin, J.; Deng, S.; Ye, X.; Zhao, M.; Wang, M.; Ye, D. Winter jujube (Zizyphus jujuba Mill.) quality forecasting method based on electronic nose. Food Chem. 2015, 170, 484-491. [CrossRef]

48. Zhang, Q.; Zhang, L.L.; Xu, J.G.; Cui, G.T. Rapid and undamaged identification of the Semen cuscutae and its adulterants based on image analysis and electronic nose analysis. J. Food Meas. Charact. 2019, 13, 3349-3356. [CrossRef]

49. Nie, J.Y.; Li, R.; Jiang, Z.T.; Wang, Y.; Tan, J.; Tang, S.H.; Zhang, Y. Antioxidant activity screening and chemical constituents of the essential oil from rosemary by ultra-fast GC electronic nose coupled with chemical methodology. J. Sci. Food Agric. 2020, 100, 3481-3487. [CrossRef]

50. Bendahou, M.; Muselli, A.; Grignon-Dubois, M.; Benyoucef, M.; Desjobert, J.M.; Bernardini, A.F.; Costa, J. Antimicrobial activity and chemical composition of Origanum glandulosum Desf. Essential oil and extract obtained by microwave extraction: Comparison with hydrodistillation. Food Chem. 2008, 106, 132-139. [CrossRef]

51. Khribch, J.; Nassik, S.; El Houadfi, M.; Zrira, S.; Oukessou, M. Activité antibactérienne de l'huile essentielle d'origan et du carvacrol sur des souches d'Escherichia coli d'origine aviaire. Rev. Maroc. Sci. Agron. Vét. 2018, 6, 300-307.

52. Kengne, L.G.; Nyegue, M.A.; Del, E.; Ndedi, F.M.; Etoa, F.X. Antibacterial activity of selected plant essential oils on airborne bacteria and mode of action on membrane integrity. Am. J. Essent. 2019, 7, 28-35.

53. Saidi, T.; Zaim, O.; Moufid, M.; El Bari, N.; Ionescu, R.; Bouchikhi, B. Exhaled breath analysis using electronic nose and gas chromatography-mass spectrometry for non-invasive diagnosis of chronic kidney disease, diabetes mellitus and healthy subjects. Sens. Actuators B Chem. 2018, 257, 178-188. [CrossRef]

54. Bueno, L.; De Araujo, W.R.; Salles, M.O.; Kussuda, M.Y.; Paixão, T.R. Voltammetric electronic tongue for discrimination of milk adulterated with urea, formaldehyde and melamine. Chemosensors 2014, 2, $251-256$. [CrossRef]

55. Murthy, K.S.R.; Reddy, M.C.; Rani, S.S.; Pullaiah, T. Bioactive principles and biological properties of essential oils of Burseraceae: A review. J. Pharmacogn. Phytochem. 2016, 5, 247.

56. Guang-Yi, L.; Bates, C.D.; Gray, A.I.; Waterman, P.G. The Volatile Oil of the Oleo Resin of Aucoumea klaineana Collected in Gabon. Planta Med. 1988, 54, 368-369. [CrossRef] [PubMed]

57. Bedounguindzi, W.F.; Candelier, K.; Edou Engonga, P.; Dumarçay, S.; Thévenon, M.F.; Gerardin, P. Caractérisations Chimiques et Activités Antitermites des Fractions Volatiles (Huile Essentielle et Résine Brute) et Lourde (Résine Purifiée) de Canarium schweinfurthii (Aiélé) du Gabon; CNRS: Paris, France, 2018.

58. Sonboli, A.; Babakhani, B.; Mehrabian, A.R. Antimicrobial activity of six constituents of essential oil from Salvia. Z. Naturforschung C J. Biosci. 2006, 61, 160-164. [CrossRef] [PubMed]

59. Satrani, B.; Ghanmi, M.; Farah, A.; Aafi, A.; Fougrach, H.; Bourkhiss, B.; Bousta, D.; Talbi, M. Composition chimique et activité antimicrobienne de l'huile essentielle de cladanthus mixtus. Bull. Soc. Pharm. Bordx. 2007, 146, 85-96.

60. Morrison, D.F. Multivariate Statistical Methods, 2nd ed.; McGraw-Hill: Singapore, 1988.

61. Umagiliyage, A.L.; Becerra-Mora, N.; Kohli, P.; Fisher, D.J.; Choudhary, R. Antimicrobial efficacy of liposomes containing d-limonene and its effect on the storage life of blueberries. Postharvest Biol. Technol. 2017, 128, 130-137. [CrossRef] 
62. Zahi, M.R.; Liang, H.; Yuan, Q. Improving the antimicrobial activity of D-limonene using a novel organogel-based nanoemulsion. Food Control 2015, 50, 554-559. [CrossRef]

63. Zhang, Z.; Vriesekoop, F.; Yuan, Q.; Liang, H. Effects of nisin on the antimicrobial activity of D-limonene and its nanoemulsion. Food Chem. 2014, 150, 307-312. [CrossRef]

64. Cristani, M.; D’Arrigo, M.; Mandalari, G.; Castelli, F.; Sarpietro, M.G.; Micieli, D.; Venuti, V.; Bisignano, G.; Saija, A.; Trombetta, D. Interaction of four monoterpenes contained in essential oils with model membranes: Implications for their antibacterial activity. J. Agric. Food Chem. 2007, 55, 6300-6308. [CrossRef]

65. Burt, S.A.; van der Zee, R.; Koets, A.P.; de Graaff, A.M.; van Knapen, F.; Gaastra, W.; Haagsman, H.P.; Veldhuizen, E.J. Carvacrol induces heat shock protein 60 and inhibits synthesis of flagellin in Escherichia coli O157:H7. Appl. Environ. Microbiol. 2007, 73, 4484-4490. [CrossRef]

66. Li, H.; Yang, T.; Li, F.Y.; Yao, Y.; Sun, Z.M. Antibacterial activity and mechanism of action of Monarda punctata essential oil and its main components against common bacterial pathogens in respiratory tract. Int. J. Clin. Exp. Pathol. 2014, 7, 7389-7398.

67. Doughari, J.H.; Ndakidemi, P.A.; Human, I.S.; Benade, S. Antioxidant, antimicrobial and antiverotoxic potentials of extracts of Curtisia dentata. J. Ethnopharmacol. 2012, 141, 1041-1050. [CrossRef]

68. Sun, X.; Wang, J.C.; Li, H.T.; Du, G.C.; Guo, D.S. A study on the antibacterial mechanism of rosmarinic acid. J. Qingdao Univ. (Nat. Sci.) 2005, 18, 41-45.

69. Shu, H.; Chen, H.; Wang, X.; Hu, Y.; Yun, Y.; Zhong, Q.; Chen, W.; Chen, W. Antimicrobial Activity and Proposed Action Mechanism of 3-Carene against Brochothrix thermosphacta and Pseudomonas fluorescens. Molecules 2019, 24, 3246. [CrossRef] [PubMed]

70. Yang, T.S.; Chao, L.K.; Liu, T.T. Antimicrobial activity of the essential oil of Glossogyne tenuifolia against selected pathogens. J. Sci. Food Agric. 2014, 94, 2965-2971. [CrossRef] [PubMed]

71. Marchese, A.; Arciola, C.R.; Barbieri, R.; Silva, A.S.; Nabavi, S.F.; Tsetegho Sokeng, A.J.; Izadi, M.; Jafari, N.J.; Suntar, I.; Dagila, M.; et al. Update on monoterpenes as antimicrobial agents: A particular focus on p-cymene. Materials 2017, 10, 947. [CrossRef] [PubMed]

72. Vaara, M. Agents that increase the permeability of the outer membrane. Microbiol. Rev. 1992, 56, 395-411. [CrossRef]

Publisher's Note: MDPI stays neutral with regard to jurisdictional claims in published maps and institutional affiliations.

(C) 2020 by the authors. Licensee MDPI, Basel, Switzerland. This article is an open access article distributed under the terms and conditions of the Creative Commons Attribution (CC BY) license (http://creativecommons.org/licenses/by/4.0/). 